\title{
Nutritional Minerals and Heavy Metals in Tea Infusions and Daily Intake of Human Body
}

\author{
Ayse Dilek Atasoy $^{1 *}$, Mehmet Irfan Yesilnacar ${ }^{2}$, Ali Yildirim ${ }^{3}$, Ahmet Ferit Atasoy ${ }^{4}$ \\ 1*Department of Environmental Engineering, Faculty of Engineering, Harran University, 63300 Sanliurfa, Turkey \\ Corresponding author: E-mail: adilekatasoy@hotmail.com, ORCID: https://orcid.org/0000-0002-8689-7300 \\ ${ }^{2}$ Department of Environmental Engineering, Faculty of Engineering, Harran University, 63300 Sanlurfa, Turkey \\ E-mail: iyesilnacar@gmail.com,ORCID: https://orcid.org/0000-0001-9724-8683 \\ ${ }^{3}$ Department of Food Engineering, Faculty of Engineering, Harran University, 63300 Sanliurfa, Turkey \\ E-mail: ayildirim@harran.edu.tr, ORCID: https://orcid.org/0000-0001-7226-1902 \\ ${ }^{4}$ Department of Food Engineering, Faculty of Engineering, Harran University, 63300 Sanliurfa, Turkey \\ E-mail: afatasoy@hotmail.com,ORCID: https://orcid.org/0000-0002-3390-1177
}

\begin{tabular}{l|l}
\hline A R T I C L E I N F O & A B S T R A C T \\
\hline Research Article & $\begin{array}{l}\text { Tea (Camellia sinensis) is one of the most popular nonalcoholic beverages in the world. During } \\
\text { tea infusion, both essential mineral elements and toxic metals are extracted into the beverage. In } \\
\text { oriental countries, almost a liter of tea is consumed daily by an average adult. Thus, high toxic } \\
\text { elements in traditional teas can be of concern. Aim of the study was to determine the essential } \\
\text { element contents and toxic heavy metal concentrations in tea products available on the market in } \\
\text { Accepted : 08/01/2019 } \\
\text { Turkey and comparing the contents of infusion for Turkish and Ceylon black and green tea types. } \\
\text { The associated health risk to tea drinkers were estimated with reference to Tolerable Daily Intake } \\
\text { (TDI) Values from US EPA for adults and children. Among the essential elements in all of the } \\
\text { black teas purchased from the market, K was present at the highest concentration followed by Mg, } \\
\text { Ca and Al. Pb and Mn contents of several tea samples were found over the Tolerable Daily Intake } \\
\text { levels. } \\
\begin{array}{l}\text { Black tea } \\
\text { Green tea } \\
\text { Heavy metal } \\
\text { Nutritional minerals } \\
\text { Tea infusion }\end{array}\end{array}$ \\
\hline
\end{tabular}

(c) $($ ) (9) This work is licensed under Creative Commons Attribution 4.0 International License

\section{Introduction}

Tea (Camellia sinensis) has gained the world's taste in the past 2000 years as one of the most popular nonalcoholic beverage. About 18 to 20 billion cups of tea are consumed daily in the world (Karak and Bhagat, 2010). Of the tea produced worldwide, $78 \%$ is black tea, which is usually consumed in the Western countries, $20 \%$ is green tea, which is commonly consumed in Asian countries, and 2\% is oolong tea which is produced (by partial fermentation) mainly in southern China (Yang and Landau, 2000). As a popular beverage, the top three tea consuming countries are Turkey, Ireland and UK (Das et al., 2017). Tea infusion is prepared by pouring boiling hot water over cured leaves of tea plant (Kottiappan et al., 2013). During tea infusion, both essential mineral elements and toxic metals are extracted into the beverage. The health benefit of tea has been well documented. However, consuming tea may provide also a significant contribution for intake and accumulation of trace metals in the human body which was not fully studied (Polechonska et al., 2015). At present, the chemical contaminants in food and drinks are becoming a global concern. As for tea, this issue has also received wide attention for the adverse effects on human health when the concentrations of some trace elements in tea infusion exceed a critical range (Lv et al., 2013). Depending on tea origin, metal accumulation can occur naturally or result from manufacturing and agronomic processes (Oliveira et al., 2018).

Presence of trace elements in tea is due to tea plants being normally grown in highly acidic soils, where trace elements are potentially more bioavailable for root uptake (Karak and Bhagat, 2010). Trace element contents of tea may have both beneficial and adverse effects on human health. The regular consumption of tea can contribute to the daily dietary requirements of some of these elements. Industrial wastes, agricultural applications, mining activities and emissions are the main pollution sources of metals in the environment. Traces of undesirable and toxic metals, i.e., $\mathrm{Cd}, \mathrm{Cr}, \mathrm{Cu}, \mathrm{Fe}, \mathrm{Ni}, \mathrm{Mn}, \mathrm{Pb}$ and $\mathrm{Zn}$ can easily contaminate tea plants (Szymczycha-Madeja et al., 2015). The growth media, nutrients, soil and agrochemical inputs contribute the contamination (Dambiec et al., 2013). However not all of the elements or metals are leached from tea to the infusion. 
In oriental countries, almost a liter of tea is consumed daily by an average adult. Thus, high toxic elements in traditional teas can be of concern. The present study, thus, aimed at determining the essential element contents and toxic heavy metal concentrations in tea products available on the market in Turkey and comparing the contents of infusion for Turkish and Ceylon black and green tea types. The associated health risk to tea drinkers were estimated with reference to Tolerable Daily Intake (TDI) Values from US EPA for adults and children (USEPA, 1992).

\section{Materials and methods}

Nine commercial Ceylon and 11 commercial Turkish teas were analyzed for $\mathrm{Al}, \mathrm{Ca}, \mathrm{Cd}, \mathrm{Cr}, \mathrm{Cu}, \mathrm{Fe}, \mathrm{Hg}, \mathrm{K}, \mathrm{Mg}$, $\mathrm{Mn}, \mathrm{Na}, \mathrm{Ni}, \mathrm{Pb}$ and $\mathrm{Zn}$ concentrations in their infusions. 6 Ceylon leaf black teas (CLB), 1 Ceylon bagged black tea (CBB), 2 Ceylon leaf green tea (CLG) and 9 Turkish leaf black tea (TLB), 1Turkish bagged black tea (TBB), 1 Turkish bagged green tea (TBG) from most demanding tea trading companies were purchased from local supermarkets in Sanliurfa, Turkey.

\section{Sample Preparations and Element Analysis}

Tea infusions were prepared by adding $100 \mathrm{~mL}$ of boiling distilled water to $2.00 \mathrm{~g}$ of tea leaves (traditional beverage method applied by tea drinkers). The tea infusion was mixed using a glass rod, covered by watch glasses to extract the components of tea leaves and allowed to brew for 10 minutes. The infusion was filtered through filter paper (Whatman 42, $125 \mathrm{~mm}$ ) into test tube, cooled and analysed immediately for $\mathrm{Al}, \mathrm{Ca}, \mathrm{Cd}, \mathrm{Cr}, \mathrm{Cu}, \mathrm{Fe}, \mathrm{Hg}, \mathrm{K}$,
$\mathrm{Mg}, \mathrm{Mn} \mathrm{Na}, \mathrm{Ni}, \mathrm{Pb}$ and $\mathrm{Zn}$ in an inductively coupled plasma (ICP) mass spectrometer (Perkin Elmer Optima 5300 DV model). All of the tests were conducted in duplicate. Concentrations of $\mathrm{Cd}$ and $\mathrm{Cr}$ in all tea infusions and $\mathrm{Ni}$ and $\mathrm{Pb}$ in some infusions were below the detection limit of $0.05 \mathrm{mg} / \mathrm{L} \mathrm{Hg}$ in all tea infusions was lower than detection limit of $0.01 \mathrm{mg} / \mathrm{L}$ (USEPA, 1992).

\section{Tolerable Daily Intake (TDI) and Daily Adequate} Intake (AI) Values

In this study, tolerable daily intake of several elements from tea infusion for adult and children was assessed. Tolerable daily intake of metals from ingestion in Table 1 was estimated following USEPA (1992) and (WORLDBANK, 2018). Adequate intake of nutritional minerals for adults and children was presented in Table 2.

$$
\text { ATDI or CTDI }=\text { TDI } \times \text { BW }
$$

Where, ATDI (mg/day) and CTDI (mg/day) is adult and children tolerable daily intake, respectively. TDI is the tolerable daily intake $(\mathrm{mg} / \mathrm{kg} / \mathrm{d})$ and $\mathrm{BW}$ is body weight (kg). For children and adults, default body weight was 20 $\mathrm{kg}$ and $70 \mathrm{~kg}$, respectively.

\section{Statistical Analysis}

The data was subjected to the statistical analysis of variance (ANOVA) and Duncan multiple range test to assess difference between means and homogeneous subsets using the SPSS 17. statistical software (SPSS Inc., USA). Statistical significance for differences was determined at $5 \%$ probability level.

Table 1 Tolerable daily intake of metals (mg/day)

\begin{tabular}{l|ccc}
\hline \multicolumn{1}{c|}{ Heavy metals } & TDI $^{*}$ oral $(\mathrm{mg} / \mathrm{kg}-\mathrm{d})$ & $\mathrm{ATDI}^{* *}(\mathrm{mg} / \mathrm{day})$ & $\mathrm{CTDI}^{* * *}(\mathrm{mg} / \mathrm{day})$ \\
\hline $\mathrm{Al}$ & 1.0000 & 70.0000 & 20.0000 \\
$\mathrm{Cd}$ & 0.0005 & 0.0350 & 0.0100 \\
$\mathrm{Cr}$ & 0.0030 & 0.2100 & 0.0600 \\
$\mathrm{Cu}$ & 0.0400 & 2.8000 & 0.8000 \\
$\mathrm{Fe}$ & 0.7000 & 49.0000 & 14.0000 \\
$\mathrm{~Pb}$ (for drinking water) & - & $0.05 \mathrm{mg} / \mathrm{L}$ & $0.05 \mathrm{mg} / \mathrm{L}$ \\
$\mathrm{Hg}$ & - & - & - \\
$\mathrm{Ni}$ & 0.0200 & 1.4000 & 0.4000 \\
$\mathrm{Mn}$ & 0.1400 & 9.8000 & 2.8000 \\
$\mathrm{Zn}$ & 0.3000 & 21.0000 & 6.0000 \\
\hline
\end{tabular}

*TDI: Tolerable Daily Intake, **ATDI: Tolerable Daily Intake for adults, ***CTDI: Tolerable Daily Intake for children

Table 2 Adequate intake of nutritional minerals (mg/day)

\begin{tabular}{l|cc}
\hline \multicolumn{1}{c|}{ Nutritional minerals } & $\left(\mathrm{AI}_{\mathrm{A}}\right)^{*}$ & $\left(\mathrm{AI}_{\mathrm{C}}\right)^{* *}$ \\
\hline $\mathrm{Ca}$ & 1200 & 800 \\
$\mathrm{Mg}$ & 308 & 120 \\
$\mathrm{~K}$ & 4700 & 3800 \\
$\mathrm{Na}$ & 2013 & 1500 \\
$\mathrm{Cu}$ & 2.25 & 1.5 \\
$\mathrm{Fe}$ & 9 & 10 \\
$\mathrm{Ni}$ & 0.175 & - \\
$\mathrm{Mn}$ & 5.3 & 1.5 \\
$\mathrm{Zn}$ & 8 & 5 \\
\hline
\end{tabular}

*Adequate intake for adults $\left(\mathrm{AI}_{\mathrm{A}}\right)(\mathrm{mg} /$ day $), * *$ Adequate intake for children $\left(\mathrm{AI}_{\mathrm{C}}\right)(\mathrm{mg} / \mathrm{day})$ 


\section{Results and Discussion}

Element concentrations in tea infusions examined in the present study were summarized in Table $3 \mathrm{a}$ and $3 \mathrm{~b}$. Concentrations of $\mathrm{Cd}, \mathrm{Cr}$, and $\mathrm{Hg}$ in all tea infusions were below the detection limits. $\mathrm{Ni}$ was found average of 0.10 $\mathrm{mg} / \mathrm{L}$ in all of the studied 11 Turkish teas; but only in 3 of the nine studied Ceylon teas as average of $0.06 \mathrm{mg} / \mathrm{L} . \mathrm{Pb}$ was found as $0.054 \mathrm{mg} / \mathrm{L}$ in only 1 Turkish leaf black tea and as $0.052 \mathrm{mg} / \mathrm{L}$ in 1 Ceylon bagged black tea sample. Their $\mathrm{Pb}$ contents are higher than the acceptable level in drinking water. $\mathrm{Pb}$ concentrations in other 18 tea infusions were below the detection limit. $\mathrm{Pb}$ is more bioavailable to tea plants growing in highly acidic soils (Han et al., 2006a, b). Leaching of $\mathrm{Pb}$ from tea leaves during soaking in boiling water is an important issue. There is a risk of exceeding the World Health Organization (WHO) limit set for $\mathrm{Pb}$ in drinking water $(0.05 \mathrm{mg} / \mathrm{L})$ by tea infusions (WHO, 2003; Brzezicha-Cirocka et al., 2016).

Among the macroelements in all of the black teas purchased from the market, $\mathrm{K}$ was present at the highest concentration with the average value of $315.98 \mathrm{mg} / \mathrm{L}$ followed by $\mathrm{Mg}, \mathrm{Ca}$ and $\mathrm{Al}$ with the average values of 16.41, 9.23 and $8.70 \mathrm{mg} / \mathrm{L}$, respectively. Such high concentrations might be explained, as Kumar et al. (2005) suggested, by the specific incorporation of $\mathrm{K}$ within a binding ligand of the tea leaves. They reported that $\mathrm{K}$ concentration in tea is higher than $\mathrm{Mg}$, while the $\mathrm{Mg}$ content is higher than $\mathrm{Na}$ one (Brzezicha-Cirocka et al., 2016). It appears that $\mathrm{Mg}$ is also quite easily extracted as a component of chlorophyll. Other alkaline earth element, i.e., $\mathrm{Ca}$ is strongly trapped inside plant cells and for that reason extraction efficiencies for these elements are relatively lower (Matsuura et al., 2001). The high content of $\mathrm{Al}$ in tea leaves may be explained by the fact that tea is one of the few Al accumulating plants (Lanhai et al., 2015). The increase in $\mathrm{Al}$ content in black tea can also be connected to the frying of leaves aimed to change the composition and stop the fermentation process that is performed using pans made of Al-Cu alloys (Fung et al., 2003). The high Mn concentrations such as average of 6.85 and $3.46 \mathrm{mg} / \mathrm{L}$ in Turkish and Ceylon black tea samples, respectively; suggest that this plant can be considered as also accumulator for $\mathrm{Mn}$ (Dambiec et al., 2013). The contribution of tea from drinking three cups daily to total exposure only in the case of $\mathrm{Al}$ and $\mathrm{Mn}$ is substantial (Polechonska et al., 2015).

In present study, average $\mathrm{K}, \mathrm{Mg}$ and $\mathrm{Zn}$ concentrations of Ceylon teas $(358,22$ and $0.37 \mathrm{mg} / \mathrm{L}$ respectively) were found higher than Turkish teas $(\mathrm{P}<0.05)(287,13$ and 0.24 $\mathrm{mg} / \mathrm{L}$, respectively). However, $\mathrm{Al}, \mathrm{Ca}, \mathrm{Fe}, \mathrm{Mn}$ and $\mathrm{Na}$ concentrations in Turkish tea infusions were higher than Ceylon $(\mathrm{P}<0.05)$. In addition there is no statistically differences between $\mathrm{Cu}$ and $\mathrm{Ni}$ concentrations in Turkish and Ceylon teas $(\mathrm{P}>0.05)$. The Ceylon and Turkish tea infusions differed a little in respect of element concentration sequences, which were as follows: $\mathrm{K}>\mathrm{Mg}$ $>\mathrm{Ca}>\mathrm{Al}>\mathrm{Mn}>\mathrm{Na}>\mathrm{Zn}>\mathrm{Fe}>\mathrm{Cu}>\mathrm{Ni}$ for Ceylon tea samples and $\mathrm{K}>\mathrm{Mg}>\mathrm{Ca}>\mathrm{Al}>\mathrm{Mn}>\mathrm{Na}>\mathrm{Zn}>\mathrm{Fe}>\mathrm{Ni}$ $>\mathrm{Cu}$ for Turkish tea infusions. The differences in results concerning elements' contents are thought to depend on tea sample origins and conditions of their cultivations.

Table 3a. Mineral and heavy metal concentrations in infusions of teas purchased from local supermarkets in Sanliurfa, Turkey $(\mathrm{mg} / \mathrm{L})^{*}$

\begin{tabular}{|c|c|c|c|c|c|c|c|c|}
\hline TI & $\mathrm{Al}$ & $\mathrm{Ca}$ & $\mathrm{Cd}$ & $\mathrm{Cr}$ & $\mathrm{Cu}$ & $\mathrm{Fe}$ & $\mathrm{Hg}$ & $\mathrm{Pb}$ \\
\hline$\overline{\text { CLB1 }}$ & $3.895 \pm 0.033^{\mathrm{b}}$ & $5.406 \pm 0.013^{\mathrm{a}}$ & BDL & BDL & $0.051 \pm 0.007^{\mathrm{a}}$ & $0.124 \pm 0.001^{\mathrm{c}}$ & BDL & $\mathrm{BDL}^{\mathrm{a}}$ \\
\hline CLB2 & $4.153 \pm 0.042^{c}$ & $7.950 \pm 0.049^{c}$ & BDL & $\mathrm{BDL}$ & $0.056 \pm 0.027^{\mathrm{a}}$ & $.047 \pm 0.031^{\mathrm{a}}$ & BDL & $\mathrm{BDL}^{\mathrm{a}}$ \\
\hline CLB3 & $4.635 \pm 0.057^{\mathrm{e}}$ & $8.363 \pm 0.037^{\mathrm{d}}$ & BDL & $\mathrm{BDL}$ & $0.066 \pm 0.031^{\mathrm{abc}}$ & $0.050 \pm 0.001^{\mathrm{a}}$ & $\mathrm{BDL}$ & $\mathrm{BDL}^{\mathrm{a}}$ \\
\hline CLB4 & $3.554 \pm 0.074^{\mathrm{a}}$ & $8.531 \pm 0.030^{\mathrm{e}}$ & BDL & BDL & $0.052 \pm 0.011^{\mathrm{a}}$ & $0.045 \pm 0.002^{\mathrm{a}}$ & BDL & $\mathrm{BDL}^{\mathrm{a}}$ \\
\hline CLB5 & $4.842 \pm 0.048^{\mathrm{f}}$ & $8.272 \pm 0.037^{\mathrm{d}}$ & BDL & BDL & $0.062 \pm 0.018^{\mathrm{ab}}$ & $0.062 \pm 0.003^{\mathrm{a}}$ & BDL & $\mathrm{BDL}^{\mathrm{a}}$ \\
\hline CLB6 & $4.447 \pm 0.059^{\mathrm{d}}$ & $9.046 \pm 0.048^{\mathrm{g}}$ & BDL & BDL & $0.056 \pm 0.017^{\mathrm{a}}$ & $0.157 \pm 0.011^{\mathrm{d}}$ & BDL & $\mathrm{BDL}^{\mathrm{a}}$ \\
\hline CLG1 & $6.137 \pm 0.078^{g}$ & $12.695 \pm 0.035^{\mathrm{r}}$ & BDL & BDL & $0.089 \pm 0.014^{\mathrm{abcd}}$ & $0.120 \pm 0.004^{c}$ & BDL & $\mathrm{BDL}^{\mathrm{a}}$ \\
\hline CLG2 & $6.356 \pm 0.068^{\mathrm{h}}$ & $16.190 \pm 0.016^{\mathrm{s}}$ & BDL & $\mathrm{BDL}$ & $0.130 \pm 0.028^{\mathrm{de}}$ & $0.209 \pm 0.021^{\mathrm{f}}$ & BDL & $\mathrm{BDL}^{\mathrm{a}}$ \\
\hline CBB1 & $6.278 \pm 0.057^{\mathrm{h}}$ & $12.09 \pm 0.102^{\mathrm{n}}$ & BDL & BDL & $0.117 \pm 0.014^{\mathrm{cde}}$ & $0.100 \pm 0.004^{\mathrm{b}}$ & BDL & $.052 \pm 0.000^{\mathrm{b}}$ \\
\hline TLB1 & $9.479 \pm 0.085^{\mathrm{j}}$ & $7.531 \pm 0.028^{\mathrm{b}}$ & BDL & BDL & $0.069 \pm 0.028^{\mathrm{abc}}$ & $0.056 \pm 0.001^{\mathrm{a}}$ & BDL & $\mathrm{BDL}^{\mathrm{a}}$ \\
\hline TLB2 & $9.210 \pm 0.042^{\mathrm{i}}$ & $9.259 \pm 0.040^{\mathrm{h}}$ & BDL & $\mathrm{BDL}$ & $0.084 \pm 0.020^{\mathrm{abcd}}$ & $0.393 \pm 0.011^{\mathrm{h}}$ & BDL & $\mathrm{BDL}^{\mathrm{a}}$ \\
\hline TLB3 & $9.134 \pm 0.048^{\mathrm{i}}$ & $9.269 \pm 0.057^{\mathrm{h}}$ & BDL & BDL & $0.080 \pm 0.014^{\mathrm{abcd}}$ & $0.056 \pm 0.006^{\mathrm{a}}$ & BDL & $\mathrm{BDL}^{\mathrm{a}}$ \\
\hline TLB4 & $14.520 \pm 0.030^{\mathrm{s}}$ & $10.395 \pm 0.014^{\mathrm{kl}}$ & BDL & BDL & $0.075 \pm 0.018 \mathrm{a}^{\mathrm{bc}}$ & $0.183 \pm 0.004^{\mathrm{e}}$ & BDL & BDL \\
\hline TLB5 & $9.707 \pm 0.040^{\mathrm{k}}$ & $10.35 \pm 0.049^{k}$ & BDL & BDL & $0.153 \pm 0.033^{\mathrm{e}}$ & $0.236 \pm 0$ & BDL & $54 \pm 0.0 \mathrm{C}$ \\
\hline TLB6 & $10.740 \pm 0.028^{\mathrm{k}}$ & $8.907 \pm 0.047^{\mathrm{f}}$ & BDL & $\mathrm{BDL}$ & $0.072 \pm 0.020^{\mathrm{abc}}$ & $0.185 \pm 0.007^{\mathrm{e}}$ & BDL & $\mathrm{BDL}^{\mathrm{a}}$ \\
\hline TLB7 & $11.550 \pm 0.035^{\mathrm{n}}$ & $10.127 \pm 0.031^{\mathrm{j}}$ & BDL & BDL & $0.072 \pm 0.014^{\mathrm{abc}}$ & $0.098 \pm 0.003^{\mathrm{b}}$ & BDL & $\mathrm{BDL}^{\mathrm{a}}$ \\
\hline TLB8 & $12.110 \pm 0.027^{p}$ & $9.555 \pm 0.057^{\mathrm{i}}$ & BDL & BDL & $0.054 \pm 0$. & $0.058 \mathrm{a} \pm \mathrm{C}$ & BDL & $\mathrm{BDL}^{\mathrm{a}}$ \\
\hline TLB9 & $13.765 \pm 0.033^{\mathrm{r}}$ & $11.410 \pm 0.040^{\mathrm{m}}$ & BDL & BDL & $0.058 \pm 0.008^{\mathrm{a}}$ & $0.181 \pm 0.010^{\mathrm{e}}$ & BDL & $\mathrm{BDL}^{\mathrm{a}}$ \\
\hline TBB1 & $15.820 \pm 0.088^{t}$ & $10.475 \pm 0.028^{1}$ & BDL & $\mathrm{BDL}$ & $0.090 \pm 0.014^{\mathrm{abcd}}$ & $0.111 \pm 0.007^{\mathrm{bc}}$ & BDL & $\mathrm{BDL}^{\mathrm{a}}$ \\
\hline TBG1 & $10.870 \pm 0.043^{\mathrm{m}}$ & $12.555 \pm 0.047^{\mathrm{p}}$ & BDL & $\mathrm{BDL}$ & $0.114 \pm 0.024^{\text {bcde }}$ & $0.512 \pm 0.008^{\mathrm{i}}$ & $\mathrm{BDL}$ & $\mathrm{BDL}^{\mathrm{a}}$ \\
\hline MTBT & $11.603 \pm 0.046^{\mathrm{B}}$ & $9.728 \pm 0.039^{\mathrm{B}}$ & BDL & BDL & $0.080 \pm 0.018$ & $0.155 \pm 0.004^{\mathrm{B}}$ & BDL & BDL \\
\hline MCBT & $4.543 \pm 0.031^{\mathrm{A}}$ & $8.522 \pm 0.045^{\mathrm{A}}$ & BDL & $\mathrm{BDL}$ & $0.065 \pm 0.005$ & $0.083 \pm 0.002^{\mathrm{A}}$ & $\mathrm{BDL}$ & BDL \\
\hline MGT & $7.788 \pm 0.063^{\mathrm{a}}$ & $13.813 \pm 0.033^{\mathrm{b}}$ & BDL & $\mathrm{BDL}$ & $0.111 \pm 0.022$ & $0.280 \pm 0.006^{\mathrm{b}}$ & BDL & BDL \\
\hline MABT & $8.696 \pm 0.040^{\mathrm{b}}$ & $9.231 \pm 0.042^{\mathrm{a}}$ & BDL & BDL & $0.074 \pm 0.013$ & $0.126 \pm 0.001^{\mathrm{a}}$ & BDL & BDL \\
\hline
\end{tabular}

TI: Tea infusions, MTBT: Mean of Turkish black teas, MCBT: Mean of Ceylon black teas, MGT: Mean of Green teas, MABT: Mean of all black teas, *Different letters indicate statistical differences within the tea samples ( $\mathrm{P}<0.05)$, BDL: Below detection limits, CLB: Ceylon leaf black tea (6), CBB: Ceylon bagged black tea (1), CLG: Ceylon leaf green tea (2), TLB: Turkish leaf black tea (9), TBB: Turkish bagged black tea (1), TBG: Turkish bagged green tea (1) 
Table $3 \mathrm{~b}$ Mineral and heavy metal concentrations in infusions of teas purchased from local supermarkets in Sanliurfa, Turkey $(\mathrm{mg} / \mathrm{L})^{*}$

\begin{tabular}{|c|c|c|c|c|c|c|}
\hline $\mathrm{TI}$ & $\mathrm{K}$ & $\mathrm{Mg}$ & $\mathrm{Mn}$ & $\mathrm{Na}$ & $\mathrm{Ni}$ & $\mathrm{Zn}$ \\
\hline CLB1 & $370.300 \pm 0.057^{r}$ & $19.120 \pm 0.028^{\mathrm{m}}$ & $3.179 \pm 0.025^{\mathrm{b}}$ & $1.947 \pm 0.086^{\mathrm{c}}$ & $\mathrm{BDL}^{\mathrm{a}}$ & $0.267 \pm 0.044^{\mathrm{def}}$ \\
\hline CLB2 & $376.250 \pm 0.055^{y}$ & $21.565 \pm 0.035^{\mathrm{s}}$ & $3.613 \pm 0.028^{\mathrm{d}}$ & $2.421 \pm 0.048^{\mathrm{g}}$ & $\mathrm{BDL}^{\mathrm{a}}$ & $0.324 \pm 0.025^{\text {hi }}$ \\
\hline CLB3 & $375.550 \pm 0.005^{\mathrm{v}}$ & $21.485 \pm 0.001^{\mathrm{r}}$ & $3.771 \pm 0.002^{\mathrm{e}}$ & $4.158 \pm 0.003^{\mathrm{m}}$ & $\mathrm{BDL}^{\mathrm{a}}$ & $0.334 \pm 0.042^{\mathrm{ij}}$ \\
\hline CLB4 & $374.900 \pm 0.006^{\mathrm{t}}$ & $19.160 \pm 0.002^{\mathrm{n}}$ & $3.204 \pm 0.001^{\mathrm{c}}$ & $1.617 \pm 0.004^{\mathrm{a}}$ & $\mathrm{BDL}^{\mathrm{a}}$ & $0.308 \pm 0.028^{\text {fghi }}$ \\
\hline CLB5 & $374.700 \pm 0.023^{\mathrm{s}}$ & $24.175 \pm 0.013^{\mathrm{v}}$ & $3.767 \pm 0.006^{\mathrm{e}}$ & $2.289 \pm 0.009^{f}$ & $\mathrm{BDL}^{\mathrm{a}}$ & $0.317 \pm 0.031^{\text {ghi }}$ \\
\hline CLB6 & $323.550 \pm 0.028^{p}$ & $21.410 \pm 0.018^{p}$ & $4.210 \pm 0.031^{\mathrm{f}}$ & $2.211 \pm 0.007^{\mathrm{e}}$ & $\mathrm{BDL}^{\mathrm{a}}$ & $0.573 \pm 0.0251$ \\
\hline CLG1 & $190.600 \pm 0.045^{\mathrm{b}}$ & $9.180 \pm 0.056^{\mathrm{b}}$ & $5.833 \pm 0.006^{\mathrm{k}}$ & $1.857 \pm 0.003^{\mathrm{b}}$ & $\mathrm{BDL}^{\mathrm{a}}$ & $0.277 \pm 0.002^{\operatorname{defg}}$ \\
\hline CLG2 & $183.750 \pm 0.067^{\mathrm{a}}$ & $9.156 \pm 0.021^{\mathrm{a}}$ & $5.607 \pm 0.014^{\mathrm{i}}$ & $4.360 \pm 0.003^{\mathrm{n}}$ & $0.057 \pm 0.002^{\mathrm{b}}$ & $0.248 \pm 0.003^{\text {bcde }}$ \\
\hline CBB1 & $309.650 \pm 0.078^{n}$ & $23.370 \pm 0.0$ & $2.502 \pm 0.007^{\mathrm{a}}$ & $4.615 \pm 0.004^{\mathrm{p}}$ & $0.062 \pm 0.001^{\mathrm{b}}$ & $0.472 \pm 0.002^{\mathrm{k}}$ \\
\hline TLB1 & $257.850 \pm 0.063^{\mathrm{d}}$ & $10.795 \pm 0.005^{\mathrm{d}}$ & $5.376 \pm 0.009^{\mathrm{g}}$ & $31.810 \pm 0.078^{t}$ & $0.083 \pm 0.002^{\mathrm{cd}}$ & $0.251 \pm 0.003^{\text {bcde }}$ \\
\hline TLB2 & $278.200 \pm 0.034^{\mathrm{g}}$ & $10.870 \pm 0.006^{\mathrm{e}}$ & $5.899 \pm 0.008^{1}$ & $3.084 \pm 0.010^{j}$ & $0.097 \pm 0.001^{\text {cdefg }}$ & $0.265 \pm 0.004^{\text {cde }}$ \\
\hline TLB3 & $277.500 \pm 0.017^{\mathrm{f}}$ & $10.810 \pm 0.012^{\mathrm{d}}$ & $5.669 \pm 0.006^{\mathrm{j}}$ & $2.021 \pm 0.002^{\mathrm{d}}$ & $0.089 \pm 0.003^{\mathrm{cde}}$ & $0.223 \pm 0.005^{\mathrm{abc}}$ \\
\hline TLB4 & $297.050 \pm 0.035^{\mathrm{j}}$ & $15.245 \pm 0.019^{\mathrm{k}}$ & $8.820 \pm 0.042^{\mathrm{t}}$ & $10.560 \pm 0.008^{\mathrm{s}}$ & $0.113 \pm 0.005^{\mathrm{g}}$ & $0.243 \pm 0.002^{\mathrm{bcd}}$ \\
\hline TLB5 & $276.700 \pm 0.021^{\mathrm{e}}$ & $10.240 \pm 0.007^{\mathrm{c}}$ & $5.519 \pm 0.004^{\mathrm{h}}$ & $3.200 \pm 0.013^{\mathrm{k}}$ & $0.079 \pm 0.007^{\mathrm{c}}$ & $0.244 \pm 0.003^{\mathrm{bcd}}$ \\
\hline TLB6 & $286.300 \pm 0.076^{\mathrm{h}}$ & $13.700 \pm 0.026^{\mathrm{g}}$ & $7.375 \pm 0.009^{\mathrm{p}}$ & $2.917 \pm 0.031^{\mathrm{i}}$ & $0.108 \pm 0.004^{\mathrm{fg}}$ & $0.214 \pm 0.001^{\mathrm{ab}}$ \\
\hline TLB7 & $302.150 \pm 0.045^{1}$ & $14.610 \pm 0.014^{j}$ & $8.050 \pm 0.011^{\mathrm{s}}$ & $3.353 \pm 0.004^{1}$ & $0.101 \pm 0.001^{\mathrm{defg}}$ & $0.217 \pm 0.002^{\mathrm{ab}}$ \\
\hline TLB8 & $298.600 \pm 0.037^{\mathrm{k}}$ & $13.545 \pm 0.012^{\mathrm{f}}$ & $6.844 \pm 0.025^{\mathrm{n}}$ & $2.772 \pm 0.018^{\mathrm{h}}$ & $0.097 \pm 0.002^{\text {cdefg }}$ & $0.188 \pm 0.003^{\mathrm{a}}$ \\
\hline TLB9 & $293.550 \pm 0.073^{\mathrm{i}}$ & $14.430 \pm 0.011^{\mathrm{i}}$ & $7.489 \pm 0.005^{\mathrm{r}}$ & $2.914 \pm 0.003^{\mathrm{i}}$ & $0.105 \pm 0.003^{\mathrm{efg}}$ & $0.219 \pm 0.006^{\mathrm{ab}}$ \\
\hline TBB1 & $298.850 \pm 0.081^{1}$ & $14.370 \pm 0.007^{\mathrm{h}}$ & $7.482 \pm 0.003^{r}$ & $2.797 \pm 0.006^{\mathrm{h}}$ & $0.103 \pm 0.001^{\mathrm{efg}}$ & $0.290 \pm 0.002^{\mathrm{efgh}}$ \\
\hline TBG1 & $237.300 \pm 0.009^{c}$ & $18.265 \pm 0.012^{1}$ & $6.018 \pm 0.003^{\mathrm{m}}$ & $4.958 \pm 0.001^{\mathrm{r}}$ & $0.094 \pm 0.002^{\text {cdef }}$ & $0.366 \pm 0.007^{j}$ \\
\hline МТBT & $286.675 \pm 0.016^{\mathrm{A}}$ & $12.862 \pm 0.006^{\mathrm{A}}$ & $6.852 \pm 0.011^{\mathrm{B}}$ & $6.543 \pm 0.007^{\mathrm{B}}$ & $0.097 \pm 0.032$ & $0.235 \pm 0.023^{\mathrm{A}}$ \\
\hline MCBT & $357.843 \pm 0.027^{\mathrm{B}}$ & $21.469 \pm 0.009^{\mathrm{B}}$ & $3.464 \pm 0.008^{\mathrm{A}}$ & $2.751 \pm 0.019^{\mathrm{A}}$ & $0.056 \pm 0.015$ & $0.370 \pm 0.028^{\mathrm{B}}$ \\
\hline MGT & $203.883 \pm 0.076^{\mathrm{a}}$ & $12.200 \pm 0.011^{\mathrm{a}}$ & $5.819 \pm 0.216$ & $3.725 \pm 0.003^{\mathrm{a}}$ & $0.075 \pm 0.010$ & $0.297 \pm 0.004$ \\
\hline MABT & $315.979 \pm 0.05^{b}$ & $16.406 \pm 0.041^{\mathrm{b}}$ & $5.457 \pm 0.128$ & $4.981 \pm 0.010^{\mathrm{b}}$ & $0.090 \pm 0.002$ & $0.291 \pm 0.011$ \\
\hline
\end{tabular}

TI: Tea infusions, MTBT: Mean of Turkish black teas, MCBT: Mean of Ceylon black teas, MGT: Mean of Green teas, MABT: Mean of all black teas, *Different letters indicate statistical differences within the tea samples ( $\mathrm{P}<0.05)$, BDL: Below detection limits, CLB: Ceylon leaf black tea (6), CBB: Ceylon bagged black tea (1), CLG: Ceylon leaf green tea (2), TLB: Turkish leaf black tea (9), TBB: Turkish bagged black tea (1), TBG: Turkish bagged green tea (1)

Average $\mathrm{Al}, \mathrm{K}, \mathrm{Mg}$, and $\mathrm{Na}$ contents of green teas with the values of $7.79,203.88,12.20$ and $3.73 \mathrm{mg} / \mathrm{L}$, respectively were found lower than $(\mathrm{P}<0.05)$ all of the studied black tea infusions. However, average $\mathrm{Ca}$ and $\mathrm{Fe}$ contents of green teas with the values 13.81 and $0.28 \mathrm{mg} / \mathrm{L}$ were found higher than $(\mathrm{P}<0.05)$ all of the studied black tea infusions. Green tea character mainly depends on leaf compositions at the time of harvesting than on compounds formed during technological processing. Moreover, the elemental composition of green tea is strongly associated with its geographical origin, genetic differences, soil composition and agricultural or climatic conditions (Khizar et al., 2015).

Tolerable and Adequate Daily Intake Values of Nutritional Elements from Tea Infusions

The regular consumption of tea may contribute to the daily requirements of some elements. Some metals found in tea (e.g., Fe, Mn, $\mathrm{Zn}$ ) are components of important enzymes or participants in a number of physiological processes so they are considered essential for the proper functioning of the human body. However, some of the other elements are undesirable or toxic to human health, such as $\mathrm{Cr}, \mathrm{Cd}, \mathrm{Ni}$, and $\mathrm{Pb}$ (Polechonska et al., 2015). Considering an average consumption of five cups or ten glasses $(1000 \mathrm{ml})$ per person per day, the percentage of the average daily intake of elements from Turkish black tea (TBT), Ceylon black tea (CBT) and green tea (GT) was determined and depicted in Table 4. The values of calculated daily intake of Mn from five cups of tea per person provide $100 \%$ of the adequate daily intake for adults and children, whereas for CBT the calculated dose is $65.35 \%$ of the adequate daily intake for adults. Tolerable daily intake levels of metals from tea infusions for adult or children were not exceeded except for $\mathrm{Mn}$ and $\mathrm{Pb}$ (Table 5). For children, Tolerable Daily Intake of $\mathrm{Mn}$ from all tea types exceeded CTDI level of $2.8 \mathrm{mg} /$ day. Tea is a rich source of the Mn and it is an essential element for a number of key enzymes including liver pyruvate carboxylase, arginase and, most notably, mitochondrial or Mndependent superoxide dismutase (Hope et al., 2006). However excess manganese can result in interference with the absorption of iron and may result in ADHD-like (Attention Hyperactivity Deficit Disorder) symptoms in children exposed in utero (Schwalfenberg et al., 2013).

Tolerable Daily Intake of $\mathrm{Pb}$ from TBT and CBT also exceeded both of the ATDI and CTDI levels of $0.05 \mathrm{mg} / \mathrm{L}$ for adult and children. $\mathrm{Pb}$ was below the detection limit in green tea samples. $\mathrm{Pb}$ causes permanent damage to key enzymes and many systems of the body including the circulatory, renal, and central nervous ones (Santos et al. 2013). Therefore, it is important to monitor the concentration of these metals, especially in view of permissible limits for growth and good health (BrzezichaCirocka et al., 2016).

The calculated daily intakes of the studied elements showed that the tea infusions could contribute toward daily intake of metals. Some important ones of these values provide $55.63 \%, 32 \%$ and $43 \%$ of adult adequate daily intake for $\mathrm{Ni}$ from $\mathrm{TBT}$, CBT and GT, respectively. Adequate daily $\mathrm{Mg}$ intake for children from TBT, CBT and GT was \%10.72, \%17.89 and \%10,17; whereas daily Zn 
intake for children was \%4.70, \%7.41 and \%5.93, respectively. Adequate daily intakes of $\mathrm{K}$ and $\mathrm{Cu}$ from TBT, CBT and GT for children were \% 7.54, \%9.42, \%5.37 and $\% 5.36, \% 4.36, \% 7.39$, respectively. For all other studied elements, adults and children adequate daily intake values were presented in Table 4. Concisely, tea contains trace elements that are essential to human health. Especially, manganese, zinc and iron play an important role in human metabolism and interest in these elements is increasing together with reports relating trace element status and oxidative diseases (Cabrera et al., 2003). However, different opinions are also there about the safety of tea drinking by taking into consideration of such nonessential or trace elements accumulation in human body. Thus, more focus should be placed on monitoring heavy metal contents in tea infusion and studying their health risk to tea consumers.

Table 4 Adequate Daily Intake of essential elements from tea infusions (\%)

\begin{tabular}{l|cccccc}
\hline \multirow{2}{*}{$\begin{array}{c}\text { Nutritional } \\
\text { minerals }\end{array}$} & \multicolumn{2}{|c}{ Percentage of adequate daily intake for adults } & \multicolumn{4}{c}{ Percentage of adequate daily intake for children } \\
\cline { 2 - 7 } & from TBT $^{*}$ & from CBT & from GT & from TBT & from CBT & from GT \\
\hline $\mathrm{Ca}$ & 0.81 & 0.71 & 1.15 & 1.22 & 1.07 & 1.73 \\
$\mathrm{Cu}$ & 3.58 & 2.91 & 4.93 & 5.36 & 4.36 & 7.39 \\
$\mathrm{Fe}$ & 1.73 & 0.92 & 3.11 & 1.55 & 0.83 & 2.80 \\
$\mathrm{~K}$ & 6.10 & 7.61 & 4.34 & 7.54 & 9.42 & 5.37 \\
$\mathrm{Mg}$ & 4.18 & 6.97 & 3.96 & 10.72 & 17.89 & 10.17 \\
$\mathrm{Mn}$ & 100.00 & 65.35 & 100.00 & 100.00 & 100.00 & 100.00 \\
$\mathrm{Na}$ & 0.33 & 0.14 & 0.19 & 0.44 & 0.18 & 0.25 \\
$\mathrm{Ni}$ & 55.63 & 32.00 & 43.00 & - & - & - \\
$\mathrm{Zn}$ & 2.94 & 4.63 & 3.71 & 4.70 & 7.41 & 5.93 \\
\hline
\end{tabular}

*TBT: Turkish black tea, ${ }^{* * \mathrm{CBT}}$ : Ceylon black tea, ${ }^{* * * \mathrm{GT}: \text { Green tea }}$

Table 5 Tolerable Daily Intake of toxic metals from tea infusions (mg/day)

\begin{tabular}{l|ccccc}
\hline Toxic metals & ATDI $^{*}$ & CTDI $^{* *}$ & Daily intake from TBT & Daily intake from CBT & Daily intake from GT $^{3}$ \\
\hline $\mathrm{Mn}$ & 9.800 & 2.800 & 6.852 & 3.464 & 5.819 \\
$\mathrm{~Pb}$ & 0.050 & 0.050 & 0.054 & 0.052 & BDL $^{4}$ \\
\hline
\end{tabular}

*ATDI: Tolerable Daily Intake for adults, ${ }^{*}{ }^{*}$ CTDI: Tolerable Daily Intake for children, ${ }^{1}$ TBT: Turkish black tea, ${ }^{2} \mathrm{CBT}$ : Ceylon black tea, ${ }^{3} \mathrm{GT}$ : Green tea, ${ }^{4}$ BDL: Below detection limits

\section{Conclusions}

Among the macroelements in all of the black teas purchased from the market, $\mathrm{K}$ was present at the highest concentration with the average value of $315.98 \mathrm{mg} / \mathrm{L}$ followed by $\mathrm{Mg}, \mathrm{Ca}$ and $\mathrm{Al}$ with the average values of $16.41,9.23$ and $8.70 \mathrm{mg} / \mathrm{L}$, respectively. Among the toxic heavy metals, concentrations of $\mathrm{Cd}, \mathrm{Cr}$ and $\mathrm{Hg}$ in all tea infusions were found below the detection limits. $\mathrm{Ni}$ and $\mathrm{Pb}$ were determined in several black tea infusions. Tolerable Daily Intake of $\mathrm{Pb}$ from TBT and CBT exceeded both of the ATDI and CTDI levels of $0.05 \mathrm{mg} / \mathrm{L}$ for adult and children. $\mathrm{Pb}$ was below the detection limit in green tea samples. The values of calculated daily intake of $\mathrm{Mn}$ from five cups of tea per person provide $100 \%$ of the adequate daily intake for adults and children, whereas for CBT the calculated dose is $65.35 \%$ of the adequate daily intake for adults. Tolerable daily intake levels of metals from tea infusions for adult or children were not exceeded except for $\mathrm{Mn}$ and $\mathrm{Pb}$. For children, Tolerable Daily Intake of $\mathrm{Mn}$ from all tea types exceeded CTDI level of $2.8 \mathrm{mg} /$ day. Tea contains trace elements that are essential to human health. However such non-essential or trace elements accumulation in human body is an important issue to be emphasized.

\section{References}

Brzezicha-Cirocka J, Grembecka M, Szefer P. 2016. Monitoring of essential and heavy metals in green tea from different geographical origins. Environ. Monit. Assess. 188-183.

Cabrera C, Gimenez R, Lopez C. 2003. Determination of tea components with antioxidant activity. J. Agric. Food Chem. 51: 4427-4435.
Dambiec M, Polechonska L, Klink A. 2013. Levels of essential and non-essential elements in black teas commercialized in Poland and their transfer to tea infusion. Journal of Food Composition and Analysis 31: 62-66.

Das S, Oliveira LM, Silva E, Liu Y, Ma LQ. 2017. Fluoride concentrations in traditional and herbal teas: Health risk assessment. Environmental Pollution 231: 779-784.

Fung KF, Zhang ZQ, Wong JWC, Wong MH. 2003. Aluminium and fluoride concentrations of three tea varieties growing at Lantau Island, Hong Kong. Environ. Geochem. Hlth. 25(2): 219-232.

Lv HP, Lin Z, Tan JF, Guo L. 2013. Contents of fluoride, lead, copper, chromium, arsenic and cadmium in Chinese Pu-erh tea. Food Research International 53: 938-944.

Han WY, Liang YR, Yang YJ, Shi YZ, Ma LF, Ruan JY, 2006a. Effect of processing on the $\mathrm{Pb}$ and $\mathrm{Cu}$ pollution of tea. Journal of Tea Science, 26: 95-101.

Han WY, Zhao FJ, Shi YZ, Ma LF, Ruan JY. 2006b. Scale and causes of lead contamination in Chinese tea. Environmental Pollution 139: 125-132.

Hope SJ, Daniel K, Gleason KL, Comber S, Nelson M, Powell JJ. 2006. Influence of tea drinking on manganese intake, manganese status and leucocyte expression of MnSOD and cytosolic aminopeptidase P. European Journal of Clinical Nutrition 60: 1-8.

WORLDBANK. 2018. World Bank Group, http://wwwesd.worldbank.org/popstoolkit/POPsToolkit/popstoolkit_co m/tools/hhra/tdi_usepa.htm

Karak T, Bhagat RM. 2010. Trace elements in tea leaves, made tea and tea infusion: a review. Food Research International 43(9): 2234-2252.

Khizar H, Hira I, Uzma M, Uzma B, Sobia M. 2015. Tea and its consumption: Benefits and risks. Critical Reviews in Food Science and Nutrition 55(7): 939-954. 
Kumar A, Nair AGC, Reddy AVR, Garg AN. 2005. Availability of essential elements in Indian and US tea brands. Food Chemistry 89: 441-448.

Lanhai L, Qing-Long F, Varenyam A, Yonglin L. 2015. A comparison of the potential health risk of aluminum and heavy metals in tea leaves and tea infusion of commercially available green tea in Jiangxi, China. Environ. Monit. Assess. 187: 228 .

Kottiappan M, Dhanakodi K, Annamalai S, Anandhan SV. 2013. Monitoring of pesticide residues in South Indian tea. Environ. Monit. Assess. 185: 6413-6417.

Matsuura H, Hokura A, Katsuki F, Itoh A, Haraguchi H. 2001. Multielement determination and speciation of major-to-trace elements in black tea leaves by ICP-AES and ICP-MS with the aid of size exclusion chromatography. Anal. Sci. 17: 391398.

Oliveira LM, Das S, Silva EB, Gao P, Gress J, Liua Y, Ma LQ. 2018. Metal concentrations in traditional and herbal teas and their potential risks to human health. Science of the Total Environment. 633: 649-657.

Polechonska L, Dambiec M, Klink A, Rudecki A. 2015. Concentrations and solubility of selected trace metals in leaf and bagged black teas commercialized in Poland. Journal of food and drug analysis 23: 486-492.
Santos LFP, Trigueiro INS, Lemos VA, Furtunato DMN, Cardoso RCV. 2013. Assessment of cadmium and lead in commercially important seafood from Sao Francisco do Conde, Bahia, Brazil. Food Control, 33: 193-199.

Schwalfenberg G, Stephen J, Genuis SJ, Rodushkin I. 2013. The Benefits and Risks of Consuming Brewed Tea: Beware of Toxic Element Contamination. Hindawi Publishing Corporation, Journal of Toxicology, Volume 2013, 8 pages.

Szymczycha-Madeja A, Welna M, Pohl P. 2015. Determination of essential and non-essential elements in green and black teas by FAAS and ICP OES simplified - multivariate classification of different tea products. Microchemical Journal 121: 122-129.

USEPA. 1992. Guidelines for Exposure Assessment, EPA/600/Z92/001. Risk Assessment Forum, Washington, DC.

WHO. 2003. Lead in drinking-water, background document for preparation of WHO Guidelines for drinking-water quality. Geneva: World Health Organization.

Yang CS, Landau JM. 2000. Effects of Tea Consumption on Nutrition and Health. American Society for Nutritional Sciences. Recent Advances in Nutritional Sciences, 130: 2409-2412. 